Marquette University

e-Publications@Marquette

$1-1-1998$

\title{
Preparation and Structures of Crystalline Aromatic Cation-Radical Salts. Triethyloxonium Hexachloroantimonate as a Novel (One-Electron) Oxidant
}

Rajendra Rathore

Marquette University

A. S. Kumar

University of Houston

Sergey V. Lindeman

Marquette University, sergey.lindeman@marquette.edu

Jay K. Kochi

University of Houston

Accepted version. The Journal of Organic Chemistry, Vol. 63, No. 17 (1998): 5847-5856. DOI. (C) 1998 American Chemical Society. Used with permission.

Sergey V. Lindeman and Rajendra Rathore were affiliated with the University of Houston at the time of publication. 
Marquette University

e-Publications@Marquette

\section{Chemistry Faculty Research and Publications/College of Arts and Sciences}

This paper is NOT THE PUBLISHED VERSION; but the author's final, peer-reviewed manuscript. The published version may be accessed by following the link in the citation below.

Journal of Organic Chemistry, Vol. 63, No. 17 (1998): 5847-5856. DOI. This article is (C) American Chemical Society and permission has been granted for this version to appear in $\underline{\text { e- }}$

Publications@Marquette. American Chemical Society does not grant permission for this article to be further copied/distributed or hosted elsewhere without the express permission from American Chemical Society.

\section{Preparation and Structures of Crystalline Aromatic Cation- Radical Salts. Triethyloxonium Hexachloroantimonate as a Novel (One-Electron) Oxidant}

$\underline{\text { R. Rathore }}$

Department of Chemistry, University of Houston, Houston, TX

A. S. Kumar

Department of Chemistry, University of Houston, Houston, TX

S. V. Lindeman

Department of Chemistry, University of Houston, Houston, TX

J. K. Kochi

Department of Chemistry, University of Houston, Houston, TX 
Abstract

$\underbrace{\mathrm{OMe}}_{\mathrm{OMe}}+\mathrm{C}_{2} \mathrm{H}_{5})_{3} \mathrm{O}^{+} \mathrm{SbCl}_{6}^{-} \longrightarrow \underbrace{\mathrm{OMe}}_{\mathrm{OMe}}$, etc.

\section{Donor \\ Meerwein's Salt \\ Cation Radical}

Triethyloxonium hexachloroantimonate $\left[\mathrm{Et}_{3} \mathrm{O}^{+} \mathrm{SbCl}_{6}\right]$ is a selective oxidant of aromatic donors $(\mathrm{ArH})$, and it allows the facile preparation and isolation of crystalline paramagnetic salts $\left[\mathrm{ArH}^{+\bullet}\right.$, $\mathrm{SbCl}_{6}{ }^{-}$for the $\mathrm{X}$-ray structure determination of various aromatic cation radicals. The mechanistic relationship between the Meerwein salt $\left[\mathrm{Et}_{3} \mathrm{O}^{+} \mathrm{SbCl}_{6}{ }^{-}\right]$and the pure Lewis acid oxidant $\mathrm{SbCl}_{5}$ is based on a prior ethyl transfer from oxygen to chlorine within the ion pair.

\section{Introduction}

Reactive cation radicals are increasingly apparent as critical reaction intermediates when aromatic and olefinic donors are exposed to various organic electrophiles $\frac{1,2}{2}$ and inorganic oxidants 3 or subjected to different electrochemical, photoinduced, and radiolytic (activation) methodologies. $\frac{4.5}{}$ Stable cation radicals also pertain directly to the contemporary interest in organic materials science for molecular devices (electrical and photoconductors, ferromagnets, sensors, optical switches, etc.). $\cdot 6,7$

Although the usual spectroscopic techniques (including UV-vis, IR, ESR, but not NMR) are available for the partial structural characterization of aromatic and olefinic cation radicals, the ultimate X-ray diffraction analysis has not been generally utilized owing to the paucity of crystalline cation radical salts. $\stackrel{-}{-}$ The latter is understandable if one considers that the presence of both cationic and radical centers usually leads to highly labile species. .9 As such, recrystallization as the standard procedure for the purification of other types of impure salts seldom leads to single crystals of X-ray size/quality. Clearly desirable is a simple chemical method for the clean separation of the pure crystalline salt directly from solution as the aromatic cation radical is generated.

Among the oxidants available for the direct separation of the cation-radical crystals are nitrosonium salts and antimony pentachloride - of particular use in the preparation of the paramagnetic thianthrenium and triarylaminium reagents, respectively. $\underline{10,11}$ As applied to hydrocarbon donors, nitrosonium salts $\left[\mathrm{NO}^{+} \mathrm{X}\right]$ also effectively oxidize various substituted benzenes and polycyclic arenes to their cation radicals even in relatively nonpolar solvents such as dichloromethane. Although the straightforward redox stoichiometry obtained with $\left[\mathrm{NO}^{+} \mathrm{X}\right]^{-12}$ (coupled with the ready in vacuo removal of the reduced nitric oxide from solution) offers an attractive methodology for the preparation of many cation-radical crystals, the competitive charge-transfer complexation of $\mathrm{NO}^{+}$with the aromatic donor $\underline{13}$ often complicates the crystallization process. Accordingly, we now turn our attention to the Lewis acid oxidant antimony $(V)$ pentachloride, ${ }^{11}$ particularly in its masked form as trialkyloxonium hexachloroantimonate $(\mathrm{V})$ salts $^{14}$ by focusing on the (1-e) oxidation of the classes of aromatic 
donors identified in Chart $1 .{ }^{15}$ Most noteworthy in this study is the successful preparation of crystalline cation-radical salts (with reduction potentials that can be as high as $E^{\circ}{ }_{\text {red }}=1.35 \mathrm{~V}$ vs SCE), which allows us to now report some typical X-ray structures of novel aromatic cation radicals.

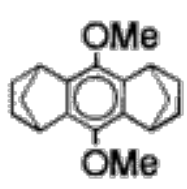

1

$\mathrm{E}_{1 / 2}(\mathrm{~V}$ vs $\mathrm{SCE})$

1.11

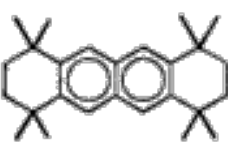

2

1.35

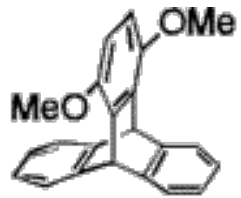

3

1.21

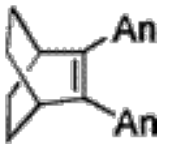

4

0.98

\section{Chart 1}

\section{Results and Discussion}

I. Oxidation of Aromatic Donors with Antimony(V) Pentachloride. The general efficacy of antimony pentachloride for the preparation of aromatic cation-radical salts was initially examined with fully substituted aromatic donors such as hydroquinone ether $\mathbf{1}$ with an oxidation potential of $E^{\mathrm{o}}{ }_{\mathrm{ox}}=1.11 \mathrm{~V}$ vs SCE. The preparative results with 1 were then compared to those obtained with the parent hydroquinone dimethyl ether $\mathbf{1 b}$ with a more positive $E^{\circ}$ ox value of $1.35 \mathrm{~V} .{ }^{15}$

A. Preparation of Crystalline Cation-Radical Salts. Treatment of the aromatic ether 1 with antimony pentachloride in dichloromethane at $-78{ }^{\circ} \mathrm{C}$ immediately resulted in a bright orangered solution from which the crystalline salt $\left[1^{+\cdot} \mathrm{SbCl}_{6}\right]$ could be isolated in quantitative yields (see Experimental Section). Establishment of the complex 3:2 stoichiometry in eq 1 was allowed by the ready separation of hexachloroantimonate salts owing to their insolubility in diethyl ether (or hexane) under conditions in which the reduced antimony(III) chloride was soluble. $\underline{16}$ When the $\mathrm{SbCl}_{5}$ oxidation of the aromatic donor 1 was slowly carried out under carefully controlled conditions (especially in hexane), crystalline orange-red needles of the cation-radical salt $\left[\mathbf{1}^{+\cdot} \mathrm{SbCl}_{6}\right]$ that were suitable for direct $\mathrm{X}$-ray diffraction analysis could be collected.

\section{$21+3 \mathrm{SbCl}_{5} \longrightarrow 2\left[1^{+\cdot} \mathrm{SbCl}_{6}^{-}\right]+\mathrm{SbCl}_{3}$}

B. Competition from Aromatic Chlorination. Treatment of $p$-dimethoxybenzene $\mathbf{1 b}$ with antimony pentachloride (under the reaction conditions for eq 1 ) yielded a rather nondescript brown solution which contained the cation radical $\mathbf{1 b}^{+\bullet}$ in only $60 \%$ yield (by spectral analysis). Reductive workup of the reaction mixture with zinc dust led to the recovery of the dimethoxybenzene, together with significant amounts of chloro-p-dimethoxybenzene, $\underline{\underline{17}}$ from which we deduced a somewhat complex reaction (eq 2). Indeed, the competitive chlorination of the aromatic donor effected by antimony pentachloride in eq 2 was reminiscent of electrophilic chlorinations of some other aromatic and olefinic donors previously observed under similar conditions. $\underline{18,19}$ 


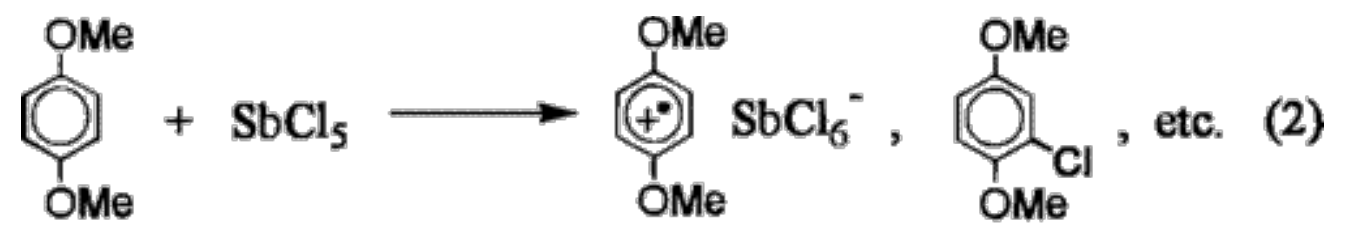

$(60 \%)$

(20\%)

\section{Selective Oxidation of Aromatic Donors with Triethyloxonium}

Hexachloroantimonate(V). To circumvent the competition from aromatic chlorination as an undesirable side reaction, we turned to hexachloroantimonate $(\mathrm{V})$ salts of trialkyloxonium cations, of which the ethyl analogue $\left[\mathrm{Et}_{3} \mathrm{O}^{+} \mathrm{SbCl}_{6}{ }^{-}\right]$was closely examined as follows.

A. Reactivity toward the Ethereal Donor 1. A slurry of triethyloxonium hexachloroantimonate and the aromatic ether 1 was stirred in dichloromethane at $0{ }^{\circ} \mathrm{C}$. The heterogeneous mixture immediately took on a bright orange-red coloration, and on continued stirring (under an argon atmosphere), it yielded a dark red (homogeneous) solution ( $1 \mathrm{~h})$. The UV-vis spectral analysis of the highly colored solution showed a characteristic spectrum with an absorption band at $\lambda_{\max }=518 \mathrm{~nm}\left(\varepsilon_{518}=7300 \mathrm{M}^{-1} \mathrm{~cm}^{-1}\right)$ and a shoulder at $486 \mathrm{~nm}$ (see Figure $1 \mathrm{~A}$ ), which was readily assigned to the cation-radical $\mathbf{1}^{+\bullet}$ by spectral comparison with that of the authentic sample $^{15 a}$ (vide supra). To optimize and quantify the amounts of cation radical formed, dichloromethane solutions of 1 containing a varying amount of $\left[\mathrm{Et}_{3} \mathrm{O}^{+} \mathrm{SbCl}_{6}\right]$ were monitored by UV-vis spectroscopy. For example, when equimolar amounts of [ $\left.\mathrm{Et}_{3} \mathrm{O}^{+} \mathrm{SbCl}_{6}{ }^{-}\right]$and $\mathbf{1}$ in dichloromethane were stirred for $1 \mathrm{~h}$, only 0.65 equiv of $\mathbf{1}^{+\bullet}$ was apparent. However, with the higher molar ratio of $\left[\mathrm{Et}_{3} \mathrm{O}^{+} \mathrm{SbCl}_{6}{ }^{-}\right]: \mathbf{1}=1.5$, a nearly quantitative (>0.98 equiv) oxidation of $\mathbf{1}$ to its cation radical was observed.

A.

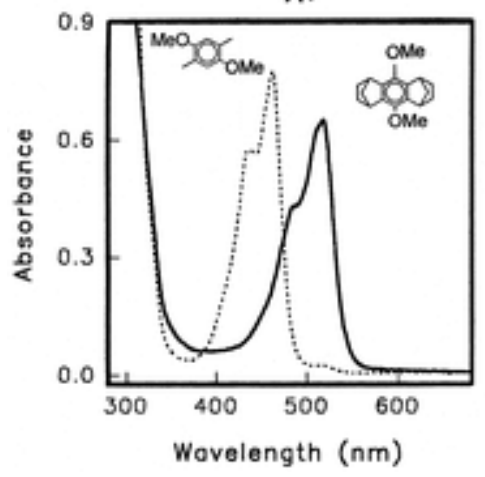

B.

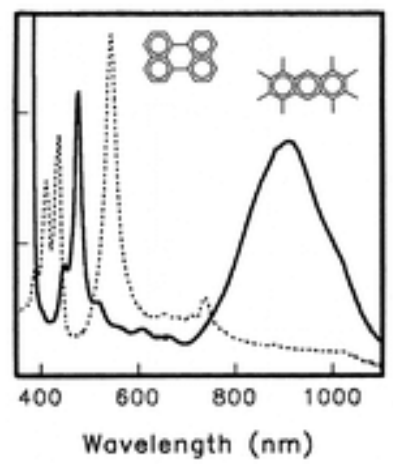

c.

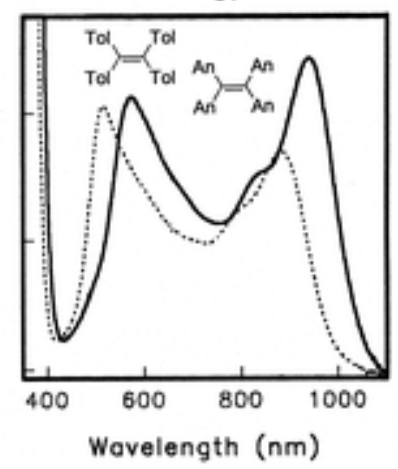

Figure 1 UV-vis absorption spectra of various cation radicals from (A) hydroquinone ethers, (B) polycyclic aromatic hydrocarbons, and (C) aryl olefin donors (as indicated) by treatment with $\left[\mathrm{Et}_{3} \mathrm{O}^{+} \mathrm{SbCl}_{6}\right]$ in dichloromethane at $0^{\circ} \mathrm{C}$.

To assess the fate of the triethyloxonium cation during the quantitative production of cation radical, the experiment was repeated in deuterated dichloromethane at $-30^{\circ} \mathrm{C}$, under otherwise the same conditions. The reaction mixture was stirred for $4 \mathrm{~h}$ to yield $\mathbf{1}^{+\bullet}$ quantitatively (as determined spectrophotometrically). After the highly colored solution was quenched with a pinch of zinc dust, an NMR analysis of the colorless dichloromethane solution 
revealed the presence of ethyl chloride and diethyl ether together with neutral donor 1 . [The identities of $\mathrm{EtCl}$ and $\mathrm{Et}_{2} \mathrm{O}$ were confirmed by spectral comparison of their NMR spectra with those of authentic samples, as described in the Experimental Section.] Accordingly, the stoichiometry for the oxidation of the aromatic donor with triethyloxonium hexachloroantimonate $(\mathrm{V})$ can be readily described as Quantitative isolation of the crystalline cation-radical salt $\left[\mathbf{1}^{+\cdot} \mathrm{SbCl}_{6}^{-}\right]$was carried out by cooling the highly colored solution to $-20^{\circ} \mathrm{C}$, followed by carefully layering it with diethyl ether, and allowing the mixture to stand undisturbed at $-20^{\circ} \mathrm{C}$. Under these conditions, the slow (quantitative) separation of dark orange-red needles of $\left[1^{+\cdot} \mathrm{SbCl}_{6}^{-}\right]$left a residual solution almost bereft of (cation-radical) color.

\section{$21+3\left[\mathrm{Et}_{3} \mathrm{O}^{+} \mathrm{SbCl}_{6}^{-}\right] \longrightarrow 2\left[1^{+\bullet} \mathrm{SbCl}_{6}^{-}\right]+3 \mathrm{EtCl}$ $+3 \mathrm{Et}_{2} \mathrm{O}+\mathrm{SbCl}_{3}$}

B. Preparation of Aromatic Cation-Radical Salts. The effectiveness of triethyloxonium hexachloroantimonate as a 1-e oxidant was examined with the series of the electron-rich hydroquinone ethers, polycyclic aromatic hydrocarbons, olefins, and heteroatom-centered donors in Table 1. In each case, treatment of the various aromatic donors with 1.5 equiv of $\left[\mathrm{Et}_{3} \mathrm{O}^{+} \mathrm{SbCl}_{6}^{-}\right]$in dichloromethane under similar reaction conditions resulted in vividly colored solutions that contained the corresponding cation radicals in excellent yields. Most importantly, the representative UV-vis absorption spectra of the cation radicals, presented in Figure 1, were identical with those obtained by either electrochemical (anodic) or chemical oxidation $\left(\mathrm{NO}^{+} \mathrm{SbCl}_{6}{ }^{-}\right.$or chloranil/methanesulfonic acid). ${ }^{15}$ Applying this general procedure, we were able to isolate highly crystalline cation radical salts of a variety of organic donors in excellent yields (see Table 1). The purity of the crystalline cation-radical salts was determined by either a spectrophotometric method or by iodometric titration (see Experimental Section). 
Table 1. Oxidation of Various Electron Donors to Their Cation Radicals with Triethyloxonium Hexachloroantimonate in Dichloromethane at $0{ }^{\circ} \mathrm{C}$ and under an Argon Atmosphere

\begin{tabular}{|c|c|c|c|c|c|c|c|c|c|}
\hline & \multirow{2}{*}{$\begin{array}{c}\text { Donor } \\
\text { (D) }\end{array}$} & \multirow[b]{2}{*}{$\mathrm{E}_{\mathrm{ox}}^{0}{ }^{\mathrm{A}}$} & \multicolumn{2}{|c|}{ Cation Radical (D+) } & \multicolumn{2}{|r|}{ Donor } & \multirow[b]{2}{*}{$\mathbf{E}_{\mathrm{ox}}^{0}{ }^{a}$} & \multicolumn{2}{|c|}{ Cation Radical (D $\left.{ }^{+}\right)$} \\
\hline & & & $\lambda_{\max }^{b}$ & $\%$ Yield $^{\circ}$ & & (D) & & $\lambda_{\max }{ }^{b}$ & $\%$ Yield \\
\hline 1 & & 1.11 & 518 & 98 & 5 & & 1.03 & 460 & 98 \\
\hline 1a & & 1.01 & 464 & 94 & 6 & & 1.05 & 476 & 98 \\
\hline $1 \mathrm{~b}$ & & 1.35 & 460 & $87^{4}$ & 7 & & 0.98 & 543 & 97 \\
\hline Ic & & 1.00 & 458 & 99 & 8 & & 0.80 & 602 & 99 \\
\hline 2 & & 1.35 & 673 & $68^{d}$ & 9 & & 1.37 & 490 & $87^{4}$ \\
\hline 3 & & 1.21 & 466 & 97 & $9 \mathrm{a}$ & & 1.12 & 516 & $98^{d}$ \\
\hline 4 & & 0.98 & 546 & 97 & $9 \mathrm{~b}$ & & 0.80 & 560 & $98^{d}$ \\
\hline
\end{tabular}

C. Limitations as an Aromatic Oxidant. The treatment of the highly nucleophilic heteroatomcentered donors such as thianthrene and phenoxithin with triethyloxonium hexachloroantimonate led to only partial formation ( 15-20\%) of corresponding cation radicals, together with substantial amounts of colorless precipitate (possibly the ethylated cation). Furthermore, the relatively electron-poor 1-methoxynaphthalene $\left(E^{p_{o x}}=1.60 \mathrm{~V}\right.$ vs $\mathrm{SCE})^{20}$ was readily oxidized with $\left[\mathrm{Et}_{3} \mathrm{O}^{+} \mathrm{SbCl}_{6}{ }^{-}\right]$, but to the corresponding dehydrodimer $\underline{21}$ in nearly quantitative yield, i.e., The fully substituted (but sterically hindered) tris-annulated benzenoid donors $\mathbf{1 0}$ and $\mathbf{1 1}$ were not converted to their cation radicals by [ $\mathrm{Et}_{3} \mathrm{O}^{+} \mathrm{SbCl}_{6}{ }^{-}$, despite their reversible oxidation potentials of $E^{\circ}{ }_{0 x}=1.51$ and $1.55 \mathrm{~V}$ vs SCE, respectively. $\underline{22}$
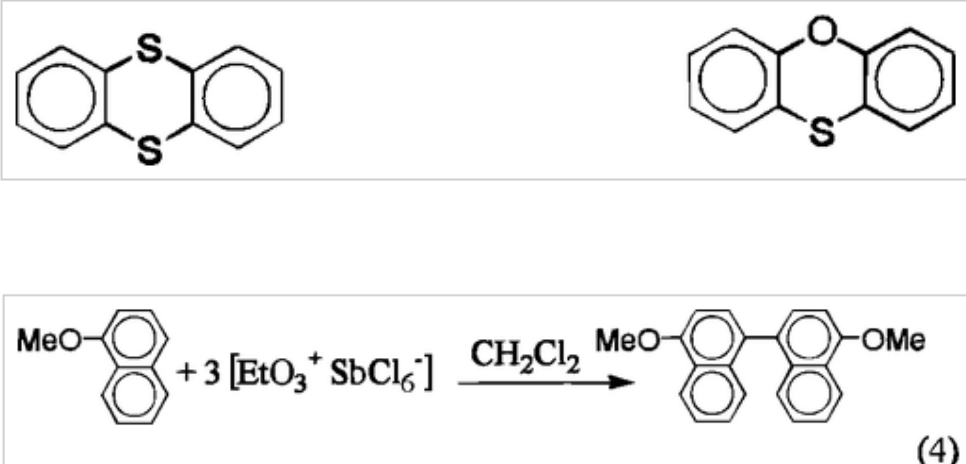


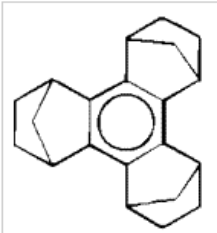

10

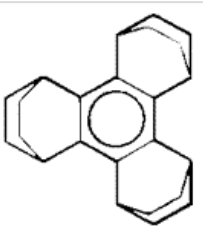

11

D. Direct Relationship to Antimony Pentachloride. The triethyloxonium cation as a member of the widely used class of alkylating agents (commonly referred to as Meerwein's salts) $\underline{23}$ was an effective oxidant for the production of aromatic cation radicals but only as the hexachloroantimonate salt. ${ }^{14 \mathrm{~b}}$ Thus the analogous triethyloxonium tetrafluoroborate under identical reactions did not afford any cation radical even after prolonged stirring (12 h) at room temperature. Similarly, mixtures of the aromatic donors in Chart 1 and tetrabutylammonium hexachloroantimonate $(\mathrm{V})$ under the same conditions never underwent color changes diagnostic of cation-radical formation. The latter is consistent with $\mathrm{SbCl}_{6}{ }^{-}$as a weak oxidizing anion (showing an irreversible anodic wave $E^{p_{\text {red }}}$ at merely $0.2 \mathrm{~V}$ ) $\underline{24}$ which is just sufficient to effect iodide oxidation, i.e., ${ }^{15 a}$

\section{$2 \mathrm{I}+\mathrm{SbCl}_{6}^{-} \longrightarrow \mathrm{I}_{2}+\mathrm{SbCl}_{4}^{-}+2 \mathrm{Cl}^{-}$(5)}

To account for the efficacy of triethyloxonium hexachloroantimonate in the oxidation of aromatic hydrocarbons with oxidation potentials as high as $E^{\circ}{ }^{\circ}=1.3 \mathrm{~V}$, we considered $\mathrm{SbCl}_{6}{ }^{-}$ as a latent form of antimony pentachloride that was unmasked by the alkylating power of the oxonium moiety, i.e., $\underline{25}$ As such, the oxonium stoichiometry for the conversion of $\mathrm{SbCl}_{6}{ }^{-}$in eq 6 plus the redox stoichiometry for $\mathrm{SbCl}_{5}$ in eq 1 coincides with the preparative (cation-radical) stoichiometry from $\left[\mathrm{Et}_{3} \mathrm{O}^{+} \mathrm{SbCl}_{6}{ }^{-}\right]$in eq 3 .

\section{$\left[\mathrm{Et}_{3} \mathrm{O}^{+} \mathrm{SbCl}_{6}^{-}\right] \stackrel{\text { [slow] }}{\longrightarrow} \mathrm{SbCl}_{5}+\mathrm{EtCl}+\mathrm{Et}_{2} \mathrm{O}$}

On the basis of eq 6 , the release of $\mathrm{SbCl}_{5}$ as the active form of $\mathrm{SbCl}_{6}{ }^{-}$must be reconciled with the singular absence of chlorinated byproducts from oxidation of the aromatic donors in Table 1 - that is otherwise obtained when antimony pentachloride itself is employed as the reactant (compare eq 2). ${ }^{18}$ This ambiguity raises an important mechanistic question as to how antimony pentachloride functions as an aromatic oxidant that leads to cation-radicals $\left(\mathrm{ArH}^{+*}\right)$ on one hand and to electrophilic chlorination products $(\mathrm{ArCl})$ on the other. An obvious distinction between these aromatic products is that $\mathrm{ArH}^{+\cdot}$ derives from the aromatic donor via a 1-e change, whereas $\mathrm{ArCl}$ involves a 2-e transformation (formally via $\mathrm{Cl}^{+}$).

As a coordinativily unsaturated Lewis acid, $\mathrm{SbCl}_{5}$ is prone to dimerization (eq 7 );르 if so, the slow release of theactive monomer in eq 6 may be responsible for electron transfer (eq 8), ${ }^{27}$ and the dimeric form may lead to electrophilic chlorination (eq 9). $\underline{\underline{28}}$ Be that as it may, further 
mechanistic studies are clearly required to delineate the pathways for antimony $(\mathrm{V})$ chloride either in form of $\left(\mathrm{SbCl}_{5}\right)_{x}$ or $\left[\mathrm{Et}_{3} \mathrm{O}^{+} \mathrm{SbCl}_{6}^{-}\right]$- as useful reagents in the preparation of cationradical salts.

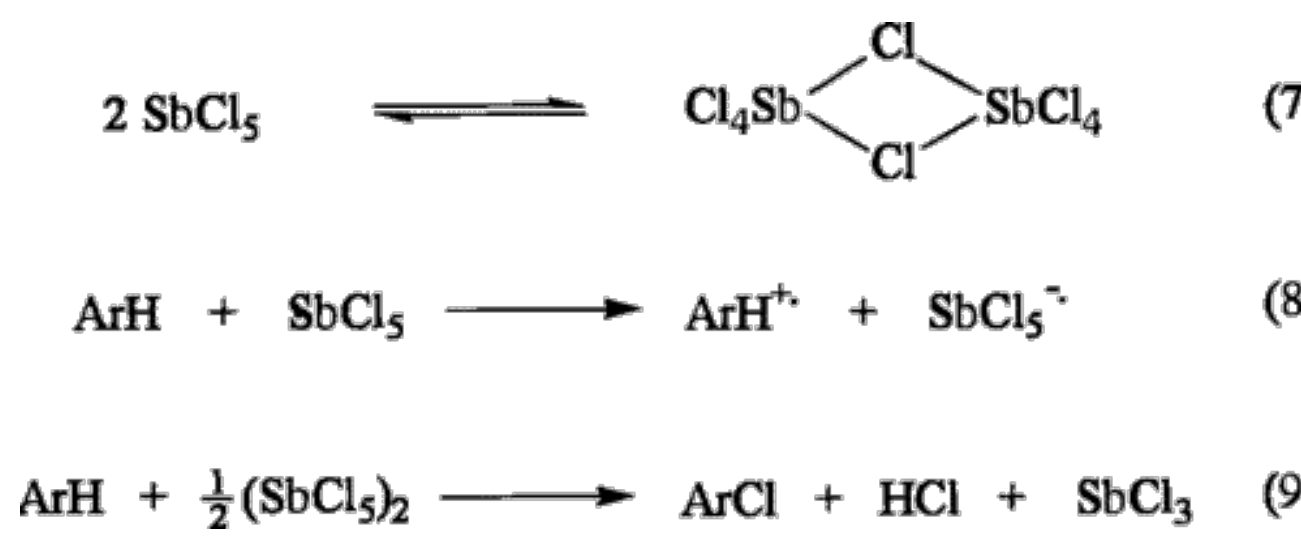

E. Practical Advantages as a One-Electron Oxidant. The slow release of $\mathrm{SbCl}_{5}$ according to eq 6, we believe, forms the basis for the efficacy of $\left[\mathrm{Et}_{3} \mathrm{O}^{+} \mathrm{SbCl}_{6}\right]$ as an aromatic oxidant in the preparation of crystalline cation-radical salts. Indeed, the rate of aromatic oxidation with $\left[\mathrm{Et}_{3} \mathrm{O}^{+} \mathrm{SbCl}_{6}^{-}\right]$can be modulated by carrying out the reaction at various temperatures (typically from 0 to $-30^{\circ} \mathrm{C}$ ) in order to optimize the slow growth of paramagnetic crystals. By contrast, the reactivity of the pure Lewis acid $\mathrm{SbCl}_{5}$ is very difficult to control, and 1-e oxidations as well as chlorinations of various aromatic donors can occur readily at even $-78{ }^{\circ} \mathrm{C} .{ }^{18,19}$ We hope that further fine-tuning of the oxidation rates will be possible with the synthesis of other trialkyloxonium salts of hexachloroantimonate with varying solubilities.

III. Structural Characterization of Aromatic Cation Radicals. The oxidative preparation of aromatic cation-radical salts made possible with triethyloxonium hexachloroantimonate allowed us to uniformly isolate single crystals suitable for $\mathrm{X}$-ray diffraction analysis. Among the various crystalline aromatic salts in Table 1, we focus here on only three that illustrate some unique structural features of cation radicals as follows.

A. Dimethoxytriptycene Cation Radical $\left(3^{+*}\right)$. Triptycene is a fundamentally important cation radical from the standpoint of intermolecular orbital interactions among the three equivalent benzenoid rings. $\underline{29}$ In the unsymmetrical 1,4 -dimethoxy derivative $3^{+\bullet}$, we further inquire as to (i) the conformation of the methoxy groups, (ii) bond lengths and the distribution of the cationic change, and (iii) the electronic consequence of charge delocalization.

(i) In the neutral hydroquinone dimethyl ether 1, the methoxy groups occupy preferred conformations out of the aromatic plane. $\frac{30}{3}$ By contrast, both methoxy groups in the cation radical $\mathbf{1}^{+\bullet}$ lie precisely in the aromatic plane, and the same coplanarity is observed in dimethoxytriptycene cation radical $\mathbf{3}^{+\bullet}$ (see Figure 2). Whereas the relative orientation of the methoxy groups is anti in $\mathbf{1}^{+\bullet}$, it is syn in $\mathbf{3}^{+\cdot}$ owing to repulsion by a pair of bridgehead hydrogens which are precisely coplanar with the ethereal aromatic plane (see Figure 2). [Note the repulsion by the bridgehead hydrogens are minimized in $\mathbf{1}^{+\cdot}$ since they are displaced away from the aromatic plane toward the methano bridges. ${ }^{15 a}$ ] 


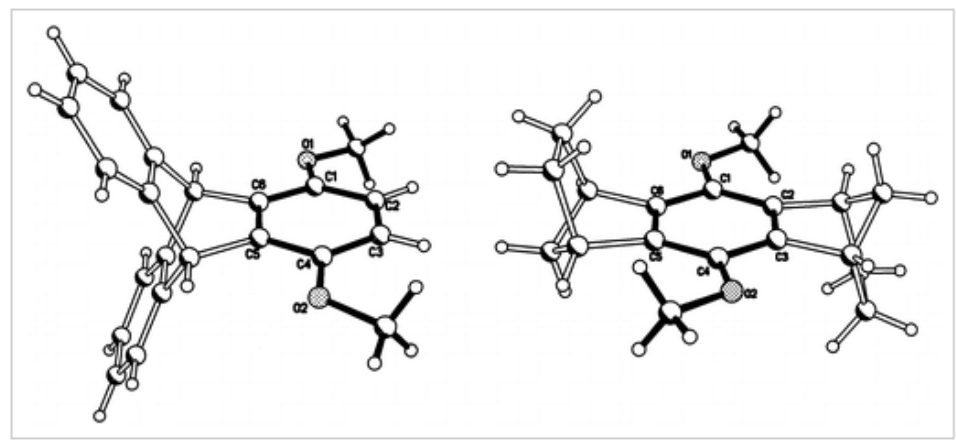

Figure 2 Comparative structures of the 1,4-dimethoxybenzene moieties in the cation radicals $\mathbf{1}^{+\bullet}$ (right) and $\mathbf{3}^{+\bullet}$ (left) showing the anti- and syn-coplanar conformations, respectively, of the pair of $\mathrm{CH}_{3} \mathrm{O}$ substituents.

(ii) In the cation radical $\mathbf{3}^{+\cdot}$, the removal of an electron from the 1,4-dimethoxybenzene moiety results in a substantial alteration in the principal bond lengths owing to a major contribution from the quinoidal structure, i.e., Such a bond alteration is summarized in Table 2 by comparing the principal $\mathrm{C}-\mathrm{C}$ and $\mathrm{C}-\mathrm{O}$ bonds in the methoxy-substituted cation radicals $\mathbf{1}^{+\bullet}$ and $3^{+\cdot}$ relative to those in the neutral ethereal donor $1 .{ }^{16 \mathrm{~b}}$ From such a bond-length comparison, it is easy to conclude that the center of cationic charge in dimethoxytriptycene cation radical residues largely if not completely on the dimethoxy-substituted ring. The latter is strongly supported by aromatic $\mathrm{C}-\mathrm{C}$ bond lengths in the pair of unsubstituted $o$-phenylene groups of $\mathbf{3}^{+\cdot}$ that are within esd to those of triptycene. $\underline{31}$

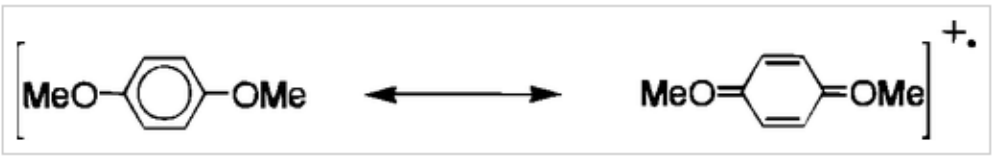

Table 2. Selected Bond Lengths of Various Hydroquinone Ether Cation Radicals and of the

Neutral Ether 1

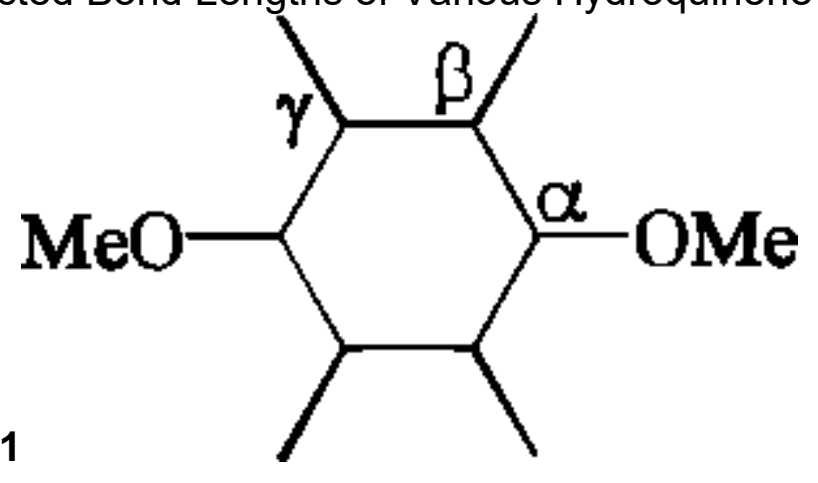
bond
1
$1^{+\cdot}$
$3^{+\cdot}$
$5^{+\cdot}$
$\mathrm{Me}-\mathrm{O}^{a}$
$1.414(3)$
$1.442(4)$
1.452(11)
1.449(6)
$\mathrm{O}-\mathrm{C}^{a}{ }^{a}$
1.391(2)
1.320(4)
1.313(11)
1.327(6) 

$\mathrm{C}_{\alpha}-\mathrm{C}_{\beta}{ }^{b}$
$1.389(2)$
$1.430(4)$
1.413(12)
1.426(8)
$\mathrm{C}_{\beta}-\mathrm{C}_{\gamma^{a}}$
$1.398(3)$
$1.378(4)$
$1.384(13)$
$1.364(7)$

${ }^{a}$ Average of two bonds. ${ }^{b}$ Average of four bonds.

(iii) The bright yellow-green color of dimethoxytriptycene cation radical derives from a weak (partially resolved) absorption appearing as a low-energy tail in the UV-vis spectrum (Figure 3). Otherwise, the principal twin $\left(\pi-\pi^{*}\right)$ absorption at $\lambda_{\max }=441$ and $466 \mathrm{~nm}(\log \varepsilon 3.44)$ is

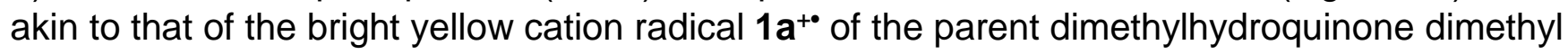
ether illustrated in Figure 1A. As such, we tentatively attribute the weak new visible band as well as the near-IR absorption in $\mathbf{3}^{+\cdot}$ to the intramolecular charge-transfer interaction between the charged $(\mathrm{MeO})_{2} \mathrm{C}_{6} \mathrm{H}_{2}$ chromophore with the phenylene groups, much in the manner previously observed as intermolecular charge-transfer interactions in cationic aromatic $\pi-$ dimers $\underline{32}$ and tropylium/arene complexes. $\frac{33}{3}$ However, the interesting molecular packing diagram in Figure 4 (with the $\mathrm{SbCl}_{6}{ }^{-}$counterion omitted for the sake of clarity) shows strong intermolecular overlap of the oxidized dimethylbenzene moiety with the benzene ring of an adjacent dimethoxytriptycene at an interplanar separation of $3.4 \AA$ that corresponds to a shortened van der Waals contact. Since the latter complicates the unambiguous analysis of the intramolecular orbital (charge-transfer) overlap among the different benzene rings in the triptycene chromophore, we hope that the synthesis of some other pertinent analogues (in progress) will provide clearer indications.

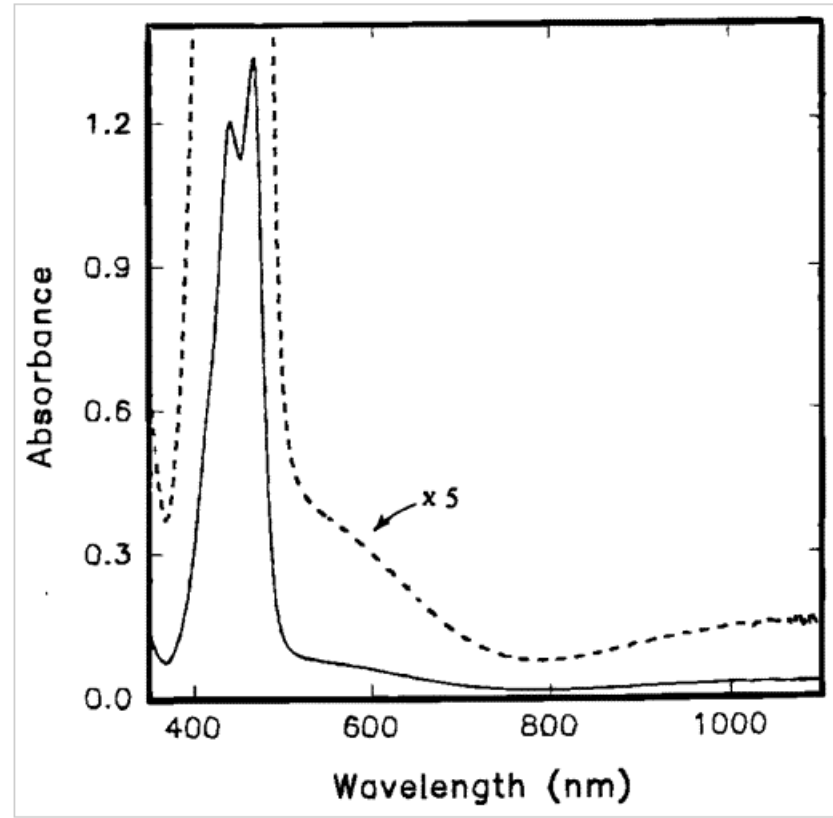

Figure 3 Low-energy absorption bands in the UV-vis absorption spectrum of dimethoxytriptycene cation radical $3^{+\cdot}\left(5 \times 10^{-4} \mathrm{M}\right)$ in dichloromethane at $22{ }^{\circ} \mathrm{C}$. The enlarged spectrum $(--)$ is magnified $\times 5$. 


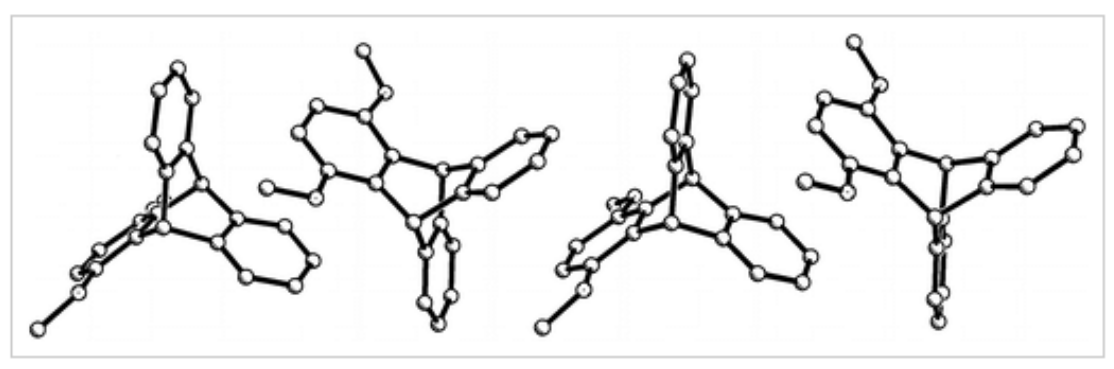

Figure 4 Molecular packing of the dimethoxytriptycene cation radical in the unit cell showing the close intermolecular interaction of the dimethoxybenzene moiety with a phenylene group in the adjacent molecule. [The $\mathrm{SbCl}_{6}{ }^{-}$counterion omitted for clarity.]

\section{B. Bichromophoric 1,4-Dimethoxy-2-methyl-5-(3'-pentamethylphenylpropyl)benzene}

Cation Radical $\mathbf{5}^{+\cdot}$. The versatility of triethyloxonium hexachloroantimonate as a selective oxidant was demonstrated with a bichromophoric donor, in which the dimethoxytoluene moiety was tethered to pentamethylbenzene via a trimethylene linkage as in $\mathbf{5}$. Indeed, the X-ray structure analysis of the dark yellow-green crystals of $\left[5^{+\cdot} \mathrm{SbCl}_{6}{ }^{-}\right]$obtained from a dichloromethane/toluene mixture at $-23^{\circ} \mathrm{C}$ established unequivocally that only the dimethoxysubstituted benzene ring suffered selective oxidation. Thus the pronounced quinoidal distortion of the (MeO) ${ }_{2} \mathrm{C}_{6}{ }^{-}$moiety in $\mathbf{5}^{+\bullet}$ was the same as that described for $\mathbf{1}^{+\bullet}$ in Table $2 .^{16 b}$

In the molecular packing diagram shown in Figure 5, the cationic ethereal ring and the anionic counterion $\mathrm{SbCl}_{6}{ }^{-}$give rise to infinite stacks of alternating cations and anions along the crystallographic $[1,0,1]$ axis. The chlorine atoms of $\mathrm{SbCl}_{6}{ }^{-}$are in a rather close contact with the cationic dimethoxybenzene ring in the range of 3.23-3.53 $\AA$. [Note that these contacts are considerably shorter than the sum of van der Waals radii for carbon $(1.7 \AA)$ and chlorine (1.8 $\AA$ ).] The pentamethylphenyl moieties are situated outside the charged stacks and are arranged in such a way that they overlap with the pentamethylphenyl moieties of neighboring stack with an interplanar separation of 3.63 and $3.69 \AA$ (for the two disordered positions). The latter may be responsible for the green tinge of the crystal which differs from the yellow solution of $\mathbf{5}^{+}$ with $\lambda_{\max }=464,488 \mathrm{~nm}$ which is the same as the absorptions in the monocyclic $\mathbf{1 b}^{+\cdot}$. 


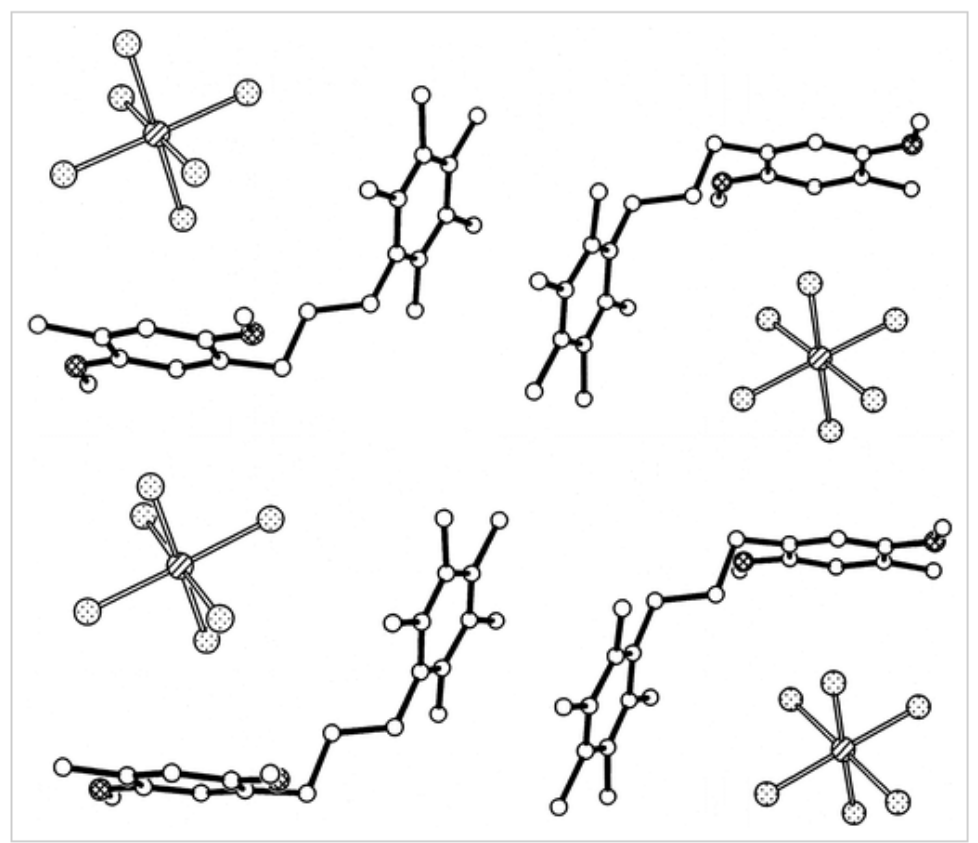

Figure 5 Structure of the tethered cation-radical salt $\left[5^{+\cdot} \mathrm{SbCl}_{6}{ }^{-}\right]$showing the ion-pair interaction of the dimethoxybenzene cation-radical center with $\mathrm{SbCl}_{6}{ }^{-}$and the close (pairwise) intermolecular interactions of the pentamethylphenyl groups in the unit cell.

C. Octamethylbiphenylene Cation Radical. The oxidation of octamethylbiphenylene 8 with triethyloxonium hexachloroantimonate in dichloromethane solution resulted in a dark blue solution from which the pure cation-radical salt $\left[8^{+\cdot} \mathrm{SbCl}_{6}{ }^{-}\right]$could only be obtained as a microcrystalline black solid unsuitable for X-ray crystallography. However, when a 2:3 mixture of octamethylbiphenylene and triethyloxonium hexachloroantimonate in dichloromethane was allowed to stand unperturbed with a layer of toluene at $-23^{\circ} \mathrm{C}$, the slow in situ crystallization afforded a crop of well-formed black crystals. X-ray structure analysis indicated that the intense (black) color arose from infinite (homosoric) stacks of octamethylbiphenylene units (tilted at a $69^{\circ}$ angle from the principal axis) which are separated by intertwined columns of hexachloroantimonate anions and some triethyloxonium cations, as illustrated in Figure 6. Quantitative analysis of the complex stoichiometry indicated the cation-radical presence as a cationic dimeric pair, i.e., (octamethylbiphenylene) ${ }^{+\cdot}$. Indeed a closer inspection of the unit cell revealed two independent intermolecular (separation) distances of 3.41 and $3.54 \AA$ between octamethylbiphenylene moieties. The difference of $0.13 \AA$ relates to the separation between dimeric units consisting of two equivalent octamethylbiphenylene structures shown in Figure $7 . \underline{34}$ 


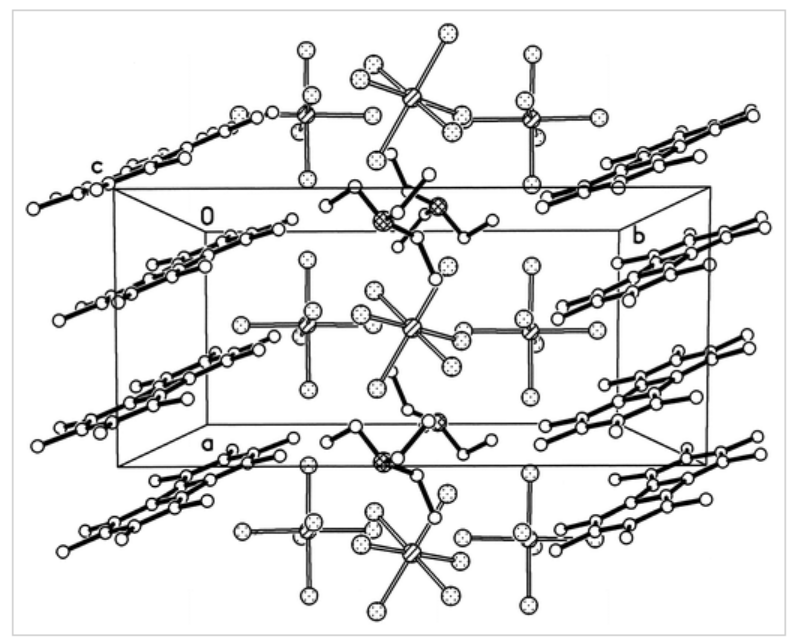

Figure 6 Homosoric stacks of the cationic octamethylbiphenylene units and the $\mathrm{SbCl}_{6}{ }^{-}$ counterions intertwined with $\left[\mathrm{Et}_{3} \mathrm{O}^{+} \mathrm{SbCl}_{6}\right]$ in the cation-radical crystal of $\left[8_{2}{ }^{+\cdot} \mathrm{SbCl}_{6}\right]$, prepared as described in the text.

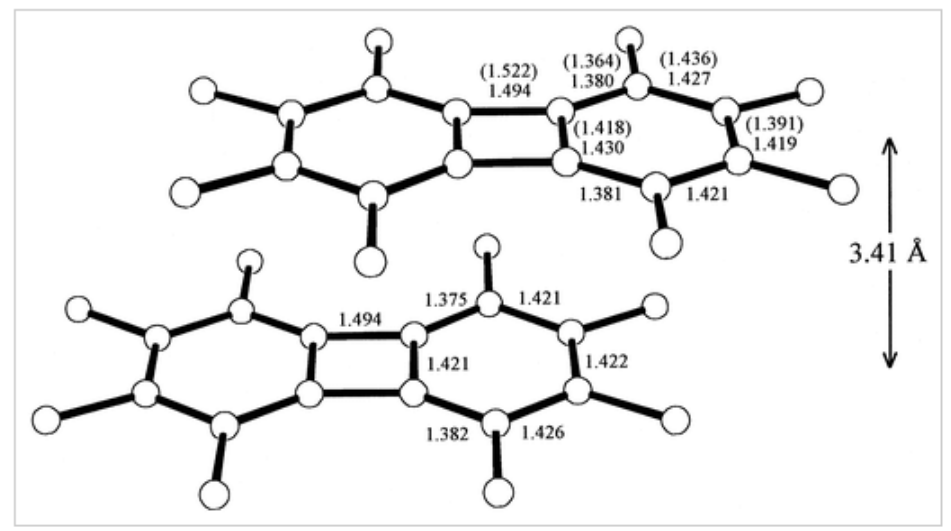

Figure 7 Molecular structure of the cationic dimer unit $(\mathbf{8}) 2_{2}^{+*}$, in which the two octamethylbiphenylenes are related by a crystallographic center of symmetry. For comparison, the bond distances in the neutral donor 8 are listed in parentheses. ${ }^{34}$

Structural comparison of the $\mathrm{C}-\mathrm{C}$ bond lengths in each of the dimeric units $(8)_{2}{ }^{+\bullet}$ revealed an alternating elongation $(0.014 \AA)$ and contraction $(0.026 \AA)$ of the $C-C$ bonds in the fourmembered ring relative to that in the neutral donor (8), ${ }^{34}$ as presented in Figure 7 . Such a distortion is undoubtedly related to the complete electron delocalization between $\mathbf{8}^{+\cdot}$ and $\mathbf{8}$ within each dimeric unit, i.e., $\underline{35}$ However, the eventual isolation of the crystalline pure cationradical salt $\left[8^{+\cdot} \mathrm{SbCl}_{6}^{-}\right]$should allow us to address the question of enhanced bond alteration in octamethylbiphenylene cation radical itself. More interestingly, the latter offers the possible observation of enhanced electrical conductivity arising from homosoric $\mathbf{8}^{+\bullet}$ stacks. ${ }^{36}$

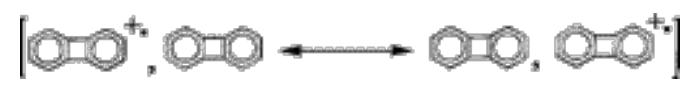




\section{Summary and Conclusions}

The Meerwein salt $\left[\mathrm{Et}_{3} \mathrm{O}^{+} \mathrm{SbCl}_{6}\right]$ is a particularly effective reagent for the preparation of crystalline cation-radical salts $\left[\mathrm{ArH}^{+\cdot} \mathrm{SbCl}_{6}^{-}\right]$where $\mathrm{ArH}$ represent various aromatic donors with oxidation potentials ${E^{\circ}}^{\circ} \leq 1.5 \mathrm{~V}$ vs SCE. Unlike the pure Lewis acid oxidant $\mathrm{SbCl}_{5}$, competition from aromatic chlorination does not generally pose a significant (byproduct) complication. As a result, crystals of pure paramagnetic salts can be prepared for the X-ray structure determination of aromatic cation radicals such as those illustrated in Figures 2, 5, and 6. The efficiency of $\left[\mathrm{Et}_{3} \mathrm{O}^{+} \mathrm{SbCl}_{6}\right]$ under conditions in which neither $\mathrm{Et}_{3} \mathrm{O}^{+}$nor $\mathrm{SbCl}_{6}{ }^{-}$is individually capable of aromatic oxidation points to the slow release of monomeric $\mathrm{SbCl}_{5}$ as the active oxidant according to eq 6.

\section{Experimental Section}

Materials. The synthesis of various electron donors such as 9,10-dimethoxy-1,4:5,8dimethano-1,2,3,4,5,6,7,8-octahydroanthracene ${ }^{15 a}$ (1), 2,5-dimethyl-1,4-dimethoxybenzene, $\underline{37}$ 2,3-bis(2,5-dimethoxy-4-methylphenyl)bicyclo[2.2.2] octane, ${ }^{38}$ octamethylbiphenylene, ${ }^{1 a}$ $1,2,3,4,7,8,9,10$-octahydro-1,1,4,4,7,7,10,10-octamethylnaphthacene, ${ }^{15 b} 1,2,3,4,5,6,7,8$ octamethylanthracene, $\underline{39}$ 2,3-bis(4-methoxyphenyl)bicyclo[2.2.2] oct-2-ene, ${ }^{38}$ 1,1,2,2-tetrakis(4methoxyphenyl)ethylene, $\underline{40}$ 1,1,2,2-tetrakis(4-methyl-phenyl)ethylene, ${ }^{40}$ phenoxthin, $\underline{41}$ and 1,4dimethoxytriptycene ${ }^{15 c}$ have been described previously. Tetraphenylethylene, 1,4dimethoxybenzene, 1-methoxynaphthalene, thianthrene, and perylene were commercially available (Aldrich) and were purified by repeated recrystallization. Trimethyl- and triethyloxonium hexachloroantimonate and tetrafluoroborate salts (Aldrich) were stored in a Vacuum Atmosphere HE-493 drybox kept free of oxygen. Tetra- $n$-butylammonium hexachloroantimonate was prepared by slow addition of $\mathrm{SbCl}_{5}$ to a dichloromethane solution of tetra- $n$-butylammonium chloride at $-20^{\circ} \mathrm{C}$. The resulting $\left[\mathrm{TBA}^{+} \mathrm{SbCl}_{6}{ }^{-}\right]$was precipitated by addition of ether and the colorless precipitate was filtered, washed with ether, and recrystallized from a mixture of dichloromethane and diethyl ether. Dichloromethane (Mallinckrodt analytical reagent) was repeatedly stirred with fresh aliquots of concentrated sulfuric acid ( 20 vol \%) until the acid layer remained colorless. After separation, it was washed successively with water, aqueous sodium bicarbonate, water, and aqueous sodium chloride and dried over anhydrous calcium chloride. The dichloromethane was distilled twice from $\mathrm{P}_{2} \mathrm{O}_{5}$ under an argon atmosphere and stored in a Schlenk flask equipped with a Teflon valve fitted with Viton O-rings. The hexane and toluene were distilled from $\mathrm{P}_{2} \mathrm{O}_{5}$ under an argon atmosphere and then refluxed over calcium hydride $(\sim 12 \mathrm{~h})$. After distillation from $\mathrm{CaH}_{2}$, the solvents were stored in the Schlenk flasks under an argon atmosphere.

\section{Synthesis of 1,4-Dimethoxy-2-methyl-5-(3'-pentamethylphenylpropyl)benzene 5. The} tethered donor was synthesized from 3-(pentamethylphenyl)propanoyl chloride ${ }^{42}$ ( $2.39 \mathrm{~g}, 10$ $\mathrm{mmol})$ and 2,5-dimethoxytoluene $(1.52 \mathrm{~g}, 10 \mathrm{mmol})$ in anhydrous dichloromethane $(25 \mathrm{~mL})$ in the presence of aluminum chloride $(2.67 \mathrm{~g}, 20 \mathrm{mmol})$ and triethylsilane $(2.91 \mathrm{~g}, 25 \mathrm{mmol})$, according to a literature procedure: $\underline{43}$ yield $86 \% ; \mathrm{mp} 116-117^{\circ} \mathrm{C}(\mathrm{EtOH}) ;{ }^{1} \mathrm{H} \mathrm{NMR}\left(\mathrm{CDCl}_{3}\right) \delta$ 1.90 (sym m, 2H), 2.35 (br s, 18H), 2.85 (m, 4H), 3.90 (s, 6H), 6.81 (s, 1H), $6.82(\mathrm{~s}, 1 \mathrm{H}) ;{ }^{13} \mathrm{C}$ $\operatorname{NMR}\left(\mathrm{CDCl}_{3}\right) \delta 16.33,16.47,16.98,17.03,28.87,30.71,30.79,56.22,56.29,112.62,113.95$, 
124.51, 128.60, 131.83, 132.52, 132.59, 136.75, 151.40, 151.62; GC-MS m/z $340\left(\mathrm{M}^{+}\right), 340$ calcd for $\mathrm{C}_{23} \mathrm{H}_{32} \mathrm{O}_{2}$. Anal. Calcd for $\mathrm{C}_{23} \mathrm{H}_{32} \mathrm{O}_{2}$ : C, 81.13; $\mathrm{H}, 9.47$. Found: $\mathrm{C}, 81.04 ; \mathrm{H}, 9.67$. The UV-vis absorption spectra were recorded on a 8450A diode array spectrometer. The ${ }^{1} \mathrm{H}$ and

${ }^{13} \mathrm{C}$ NMR spectra were obtained on a General Electric QE-300 FT NMR spectrometer.

General Procedure for the Preparative Isolation of Cation-Radical Salts Using [ $\mathrm{Et}_{3} \mathrm{O}^{+} \mathrm{SbCl}_{6}{ }^{-}$. A $200-\mathrm{mL}$ flask equipped with a Schlenk adapter was charged with triethyloxonium hexachloroantimonate $(657 \mathrm{mg}, 1.5 \mathrm{mmol})$, and a solution of the hydroquinone ether 1 (270 mg, $1 \mathrm{mmol})$ in anhydrous dichloromethane $(25 \mathrm{~mL})$ was added under an argon atmosphere at $\sim 0{ }^{\circ} \mathrm{C}$. The heterogeneous mixture immediately took on a red-orange coloration which intensified with time. The dark colored mixture was stirred for $2 \mathrm{~h}$ to yield a dark red solution of $\mathbf{1}^{+\cdot}\left[\lambda_{\max }(\mathrm{nm})=518,486(\mathrm{sh})\right.$, see Figure 1]. The dark red solution was cooled to $-20{ }^{\circ} \mathrm{C}$ in an ice-salt bath, and anhydrous diethyl ether $(100 \mathrm{~mL})$ was added to precipitate the dissolved salt. The orange-red precipitate was filtered under an argon atmosphere, washed with diethyl ether $(3 \times 25 \mathrm{~mL})$, and dried in vacuo. The highly pure cation radical [1+. $\left.\mathrm{SbCl}_{6}^{-}\right]$ (vide infra) was obtained in essentially quantitative yield $(592 \mathrm{mg}, 0.98 \mathrm{mmol})$.

Determination of Purity of the Cation-Radical Salts. The purity of the isolated cation radical hexachloroantimonate salts was determined either by a spectrophotometric method or by iodometric titration. The general procedures described for $\left[\mathbf{1}^{+\cdot} \mathrm{SbCl}_{6}^{-}\right]$were employed for determination of the purity of other cation radicals in Table 1 , and they were found to be uniformly greater than $98 \%$. Spectrophotometric Method. A known quantity of $\left[1^{+\cdot} \mathrm{SbCl}_{6}^{-}\right]$ $\left(4.14 \mathrm{mg}, 6.85 \times 10^{-3} \mathrm{mmol}\right.$ ) was dissolved in anhydrous dichloromethane $(50 \mathrm{~mL})$ at $22{ }^{\circ} \mathrm{C}$, under an argon atmosphere. The UV-vis spectral analysis of the red-orange solution showed an absorbance $=0.986$ at the maximum $\left(\lambda_{\max }=518 \mathrm{~nm}\right)$. We then calculated the concentration of the cation radical $=\left[6.75 \times 10^{-3} \mathrm{M}\right]$ using $\left[\mathbf{1}^{+\cdot} \mathrm{SbCl}^{-}\right]=$absorbance $/ \varepsilon$, where $\varepsilon 518=7300 \mathrm{M}^{-1}$ $\mathrm{cm}^{-1}$ is the extinction coefficient of $\mathbf{1}^{+\bullet}$ at the maximum. lodometric Method. A solution of [1 $\left.{ }^{+\circ} \mathrm{SbCl}_{6}^{-}\right](60.45 \mathrm{mg}, 0.01 \mathrm{M})$ in dichloromethane was added to a dichloromethane solution containing excess tetra- $n$-butylammonium iodide $(1 \mathrm{mmol}, 0.1 \mathrm{M})$ at $22^{\circ} \mathrm{C}$ under an argon atmosphere to afford a dark brown solution. The mixture was stirred for $5 \mathrm{~min}$ and was titrated (with rapid stirring) by a slow addition of a standard aqueous sodium thiosulfate solution ( 0.005 $\mathrm{M}$ ) in the presence of a starch solution as an internal indicator. On the basis of the amount of thiosulfate solution consumed $(59.4 \mathrm{~mL})$, purity of the cation radical was determined to be $>99 \%$.

The various cation-radical salts listed below were prepared and the purity of isolated salts was determined using the general procedures described above. The details and characteristic spectral data are presented as follows. 9,10-Dimethoxy-1,4:5,8-dimethano-1,2,3,4,5,6,7,8octahydroanthracene cation radical hexachloroantimonate $\left[\left(\mathrm{C}_{18} \mathrm{H}_{22} \mathrm{O}_{2}\right)^{+} \mathrm{SbCl}_{6}{ }^{-}\right]$: orangered needles; UV-vis $\left(\mathrm{CH}_{2} \mathrm{Cl}_{2}\right) \wedge(\log \varepsilon) 518$ (3.86), 486 (sh) nm; calcd 604.5, found 609 (iodometric method). 2,5-Dimethyl-1,4-dimethoxybenzene cation radical hexachloroantimonate $\left[\left(\mathrm{C}_{10} \mathrm{H}_{14} \mathrm{O}_{2}\right)^{+\cdot} \mathrm{SbCl}_{6}\right]$ : dark yellow-green solid; UV-vis $\left(\mathrm{CH}_{2} \mathrm{Cl}_{2}\right) \wedge(\log$ ع) 464 (4.02), 448 (sh) nm; exact mass 500.5, found 507 (iodometric method). 1,4Dimethoxybenzene cation radical hexachloroantimonate $\left[\left(\mathrm{C}_{8} \mathrm{H}_{10} \mathrm{O}_{2}\right)^{+\cdot} \mathrm{SbCl}_{6}^{-}\right]$: intense 
yellow-green solution; UV-vis $\left(\mathrm{CH}_{2} \mathrm{Cl}_{2}\right) \lambda(\log \varepsilon) 460$ (4.02), 440 (sh) nm; exact mass calcd 472.5. 2,3-Bis(2,5-dimethoxy-4-methylphenyl)bicyclo[2.2.2]octane hexachloroantimonate $\left[\left(\mathrm{C}_{26} \mathrm{H}_{34} \mathrm{O}_{4}\right)^{+\cdot} \mathrm{SbCl}_{6}{ }^{-}\right]$:yellow-green powder; UV-vis $\left(\mathrm{CH}_{2} \mathrm{Cl}_{2}\right) \lambda(\log \varepsilon) 458$ (3.63) nm; exact mass calcd 744.5, found 761 (iodometric method). 1,2,3,4,7,8,9,10-Octahydro$1,1,4,4,7,7,10,10$-octamethylnaphthacene cation radical hexachloroantimonate $\left[\mathrm{C}_{26} \mathrm{H}_{36}{ }^{+} \mathrm{SbCl}_{6}\right]$ ]:dark blue solution; UV-vis $\left(\mathrm{CH}_{2} \mathrm{Cl}_{2}\right) \lambda(\log \varepsilon) 672$ (3.68), 616, 456, 503, 412, $396 \mathrm{~nm}$; exact mass calcd 682.5. 1,4-Dimethoxytriptycene cation radical hexachloroantimonate $\left[\left(\mathrm{C}_{22} \mathrm{H}_{18} \mathrm{O}_{2}\right)^{+\cdot} \mathrm{SbCl}_{6}{ }^{-}\right]$:dark green prisms; UV-vis $\left(\mathrm{CH}_{2} \mathrm{Cl}_{2}\right) \lambda(\log \varepsilon) 466$ (3.44), 441, 550 (sh), 1050 nm; exact mass calcd 648.5, found 640 (by iodometric method). 1,4-Dimethoxy-2-methyl-5-(3-pentamethylpropyl)benzene cation radical hexachloroantimonate $\left[\left(\mathrm{C}_{23} \mathrm{H}_{32} \mathrm{O}_{2}\right)^{+\cdot} \mathrm{SbCl}_{6}{ }^{-}\right]$:dark green micro crystals; UV-vis $\left(\mathrm{CH}_{2} \mathrm{Cl}_{2}\right) \lambda(\log$ ع) 460 (3.84), 440 (sh), 800 (br); exact mass 674.5, found 680 (iodometric method).

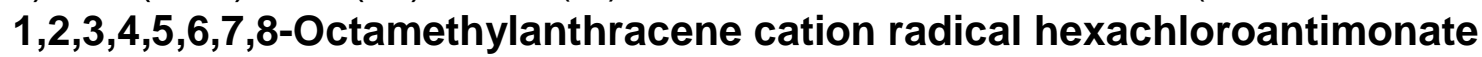
[( $\left.\left.\mathrm{C}_{22} \mathrm{H}_{26}\right)^{+\cdot} \mathrm{SbCl}_{6}{ }^{-}\right]$: dark greenish powder; UV-vis $\left(\mathrm{CH}_{2} \mathrm{Cl}_{2}\right) \wedge(\log \varepsilon) 476$ (4.16), 448, $910 \mathrm{~nm}$; exact mass calcd 624.5, found 634 (by iodometric method). Perylene cation radical hexachloroantimonate $\left[\left(\mathrm{C}_{20}-\mathrm{H}_{12}\right)^{+\cdot}\right.$ SbCl6 $\left.{ }^{-}\right]$: dark red cotton-like needles; UV-vis $\left(\mathrm{CH}_{2} \mathrm{Cl}_{2}\right) \lambda$ ( $\log \varepsilon$ ) 543 (4.50), 737, 719, $680 \mathrm{~nm}$; exact mass calcd 586.5, found 600 (by iodometric method). Octamethylbiphenylene cation radical hexachloroantimonate $\left[\left(\mathrm{C}_{20} \mathrm{H}_{24}\right)^{+\cdot} \mathrm{Sb}-\mathrm{Cl}_{6}{ }^{-}\right]$: dark black powder; UV-vis $\left(\mathrm{CH}_{2} \mathrm{Cl}_{2}\right) \lambda(\log \varepsilon) 602$ (4.08), 550 (sh) nm; exact mass calcd 598.5, found 585 (by iodometric method). 2,3-Bis(4-methoxyphenyl)bicyclo[2.2.2]oct-2-ene cation radical $\left[\left(\mathrm{C}_{22} \mathrm{H}_{24}\right)^{+\cdot} \mathrm{SbCl}_{6}^{-}\right]$: magenta red solution; UV-vis $\left(\mathrm{CH}_{2} \mathrm{Cl}_{2}\right) \wedge(\log \varepsilon) 546(4.16), 492$ $(\mathrm{sh}), 880 \mathrm{~nm}$. Tetraphenylethylene cation radical hexachloroantimonate $\left[\left(\mathrm{C}_{26} \mathrm{H}_{20}\right)^{+\cdot} \mathrm{SbCl}_{6}\right.$ ]: dirty red solution; UV-vis $\left(\mathrm{CH}_{2} \mathrm{Cl}_{2}\right) \lambda(\log \varepsilon) 490$ (3.99), $850 \mathrm{~nm}$; exact mass calcd 666.5. Tetrakis(4-methylphenyl)ethylene cation radical $\left[\left(\mathrm{C}_{30}-\mathrm{H}_{28}\right)^{+\cdot} \mathrm{Sb}-\mathrm{Cl}_{6}\right]$ : purple solution; UV-vis $\left(\mathrm{CH}_{2} \mathrm{Cl}_{2}\right) \lambda(\log \varepsilon) 516$ (4.18), $885 \mathrm{~nm}$; exact mass calcd 722.5. Tetrakis(4-methoxyphenyl)ethylene cation radical $\left[\left(\mathrm{C}_{30} \mathrm{H}_{28} \mathrm{O}_{2}\right)^{+\cdot} \mathrm{SbCl}_{6}\right]$ : blue solution; UV-vis $\left(\mathrm{CH}_{2} \mathrm{Cl}_{2}\right) \lambda(\log \varepsilon)$ 560 (4.28), $926 \mathrm{~nm}$; exact mass calcd. 754.5.

Characterization of the Products Derived from the Triethyloxonium Cation during Oxidation. A solution of hydroquinone ether $1(52 \mathrm{mg}, 0.2 \mathrm{mmol})$ in $2 \mathrm{~mL}$ of deuterated dichloromethane was treated with 1.5 equiv of $\left[\mathrm{Et}_{3} \mathrm{O}^{+} \mathrm{SbCl}_{6}\right]$ (131 $\left.\mathrm{mg}, 0.3 \mathrm{mmol}\right)$ under an argon atmosphere at $-30^{\circ} \mathrm{C}$. The reaction mixture was stirred for $4 \mathrm{~h}$, and an aliquot was removed with the aid of a hypodermic syringe. Dilution with dichloromethane and UV-vis spectral analysis showed the quantitative formation of cation radical $\mathbf{1}^{+\cdot}$. The reaction mixture was quenched by addition of a pinch of zinc dust. The colorless liquid was carefully transferred at $-30{ }^{\circ} \mathrm{C}$ with the aid of a cannula to a NMR tube. The $\mathrm{CD}_{2} \mathrm{Cl}_{2}$ solution was spectrally (NMR) analyzed to show the presence of diethyl ether $\left[{ }^{1} \mathrm{H}\right.$ NMR $\left.\delta 1.21(\mathrm{t}, 6 \mathrm{H}), 1.42(\mathrm{q}, 4 \mathrm{H})\right]$ and ethyl chloride [ ${ }^{1} \mathrm{H}$ NMR $\left.\delta 1.29(\mathrm{t}, 3 \mathrm{H}), 1.33(\mathrm{q}, 2 \mathrm{H})\right]$ together with neutral 1.

Oxidative Coupling of 1-Methoxynaphthalene with [ $\left.\mathrm{Et}_{3} \mathrm{O}^{+} \mathrm{SbCl}_{6}^{-}\right]$. A flask was charged with [ $\left.\mathrm{Et}_{3} \mathrm{O}^{+} \mathrm{SbCl}_{6}^{-}\right]$(438 mg, $\left.1 \mathrm{mmol}\right)$ and a solution of 1-methoxynaphthalene $(158 \mathrm{mg}, 1 \mathrm{mmol})$ in anhydrous dichloromethane $(20 \mathrm{~mL})$ was added under an argon atmosphere. The colorless suspension was stirred at room temperature for $1 \mathrm{~h}$ to yield a pale brown solution. The reaction mixture was quenched with a saturated aqueous sodium bicarbonate solution $(40 \mathrm{~mL})$ and was 
diluted with dichloromethane $(30 \mathrm{~mL})$. The organic layer was separated, washed with water (2 $\times 25 \mathrm{~mL}$ ), and dried over anhydrous magnesium sulfate. Removal of solvent in vacuo afforded nearly a quantitative yield (302 mg, 96\%) of pure 4,4'-dimethoxy-1,1'-binaphthyl [mp 252-254 ${ }^{\circ} \mathrm{C}$ (lit. ${ }^{21} \mathrm{mp} 254-255^{\circ} \mathrm{C}$ )]. The identity of the naphthalene dimer was further confirmed by GC and GC-MS comparison with that of an authentic sample. ${ }^{21}$

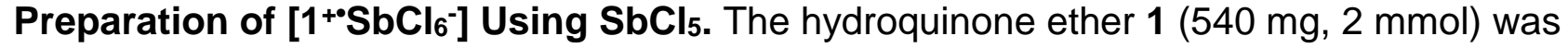
dissolved in anhydrous dichloromethane $(10 \mathrm{~mL})$ under an argon atmosphere in a $100 \mathrm{~mL}$ flask equipped with a Schlenk adapter and a rubber septum. The flask was cooled in a dry ice-acetone bath $\left(\sim-78{ }^{\circ} \mathrm{C}\right)$, and a dichloromethane solution of $\mathrm{SbCl}_{5}(0.3 \mathrm{M}, 10 \mathrm{~mL})$ was added slowly with the aid of a Teflon cannula under a flow of argon. The solution immediately turned deep orange red, and a large amount of crystalline material precipitated. The resultant mixture was warmed slowly to $0^{\circ} \mathrm{C}$ and was stirred for a further 10 min at $0{ }^{\circ} \mathrm{C}$; anhydrous diethyl ether $(40 \mathrm{~mL})$ was added to precipitate the dissolved cation-radical salt. The orange-red precipitate was filtered under an argon atmosphere and washed thoroughly with anhydrous diethyl ether $(3 \times 10 \mathrm{~mL})$. The microcrystalline $\left[1^{+\cdot} \mathrm{SbCl}_{6}^{-}\right]$salt was dried at room temperature $\left(\sim 22{ }^{\circ} \mathrm{C}\right)$ in vacuo to afford fine orange-red needle shaped crystals in nearly quantitative yield $(1.18 \mathrm{~g}, 97.6 \%)$. The purity of the cation radical salt was determined iodometrically to be greater than $99 \%$.

Reaction of $\boldsymbol{p}$-Dimethoxybenzene with $\mathrm{SbCl}_{5}$. A solution of $p$-dimethoxybenzene $(276 \mathrm{mg}, 2$ $\mathrm{mmol})$ in anhydrous dichloromethane $(10 \mathrm{~mL})$ was placed in a $100-\mathrm{mL}$ flask equipped with a Schlenk adapter and a rubber septum. The solution was cooled in a dry ice-acetone bath (approximately $-78{ }^{\circ} \mathrm{C}$ ), and a dichloromethane solution of $\mathrm{SbCl}_{5}(0.3 \mathrm{M}, 10 \mathrm{~mL}$ ) was added slowly with the aid of a Teflon cannula under a flow of argon. The dark brown reaction mixture thus obtained was warmed to $-20^{\circ} \mathrm{C}$ and was stirred for an additional $10 \mathrm{~min}$. Anhydrous diethyl ether $(50 \mathrm{~mL})$ was added with the aid of a hypodermic syringe, and a dark oily residue separated which did not crystallize even after prolonged stirring $(\sim 2 \mathrm{~h})$ at $-20{ }^{\circ} \mathrm{C}$. The mixture was treated with zinc dust $(\sim 1 \mathrm{~g})$ and was stirred for $10 \mathrm{~min}$. The colorless solution was filtered and washed with aqueous sodium bicarbonate $(30 \mathrm{~mL})$ and water $(30 \mathrm{~mL})$. Removal of solvent yielded an oily residue which upon GC and GC-MS analysis (internal standard method) showed a mixture of $p$-dimethoxybenzene (174 mg, 63\%), chloro-p-dimethoxybenzene ${ }^{17}$ (59 $\mathrm{mg}, 17 \%)$, and several unidentified products.

Isolation and X-ray Crystallography of Cation-Radical Hexachloroantimonate Salts. The intensity data were collected with the aid of a Siemens SMART diffractometer equipped with a CCD detector using Mo Ka radiation $(\lambda=0.71073 \AA)$, at $-150^{\circ} \mathrm{C}$ unless otherwise specified. The structures were solved by direct methods ${ }^{44}$ and refined by full matrix least-squares procedure with IBM Pentium and SGI $\mathrm{O}_{2}$ computers. [Note that the $\mathrm{X}$-ray structure details of various compounds mentioned here are on deposit and can be obtained from Cambridge Crystallographic Data Center, U.K.] 1,4-Dimethoxytriptycene Cation Radical $\left[\left(\mathrm{C}_{22} \mathrm{H}_{18} \mathrm{O}_{2}\right)^{+\cdot} \mathrm{SbCl}_{6}^{-}\right]$. A microcrystalline cation radical salt of dimethoxytriptycene (obtained from the general procedure described above) was dissolved in anhydrous dichloromethane under an argon atmosphere. The deep yellow-green solution was carefully layered with 
anhydrous hexane $(30 \mathrm{~mL})$ and carefully placed in a refrigerator $\left(-23^{\circ} \mathrm{C}\right)$. During the course of 7 days, bright yellow-green crystals of cation-radical salt were deposited. An intensely colored crystal with dimensions $(0.4 \times 0.3 \times 0.2 \mathrm{~mm})$ was used for X-ray structural study. MW $=$ 648.81, monoclinic, space group Cc, $a=24.1027(13), b=7.8398(5)$, and $c=13.5936(8) \AA, D_{c}$ $=1.740 \mathrm{mg} \mathrm{m}^{-3}, V=2477.2(3) \AA^{3}, Z=4$. The total number of reflections measured was 12007 , of which 6250 reflections were symmetrically nonequivalent. Final residuals were $R_{1}=0.0679$ and $\mathrm{w} R_{2}=0.1209$ for 6328 reflections with $I>2 \sigma\left(I_{0}\right)$. 1,4-Dimethoxy-2-methyl-5-(3'pentamethylphenylpropyl)benzene Cation Radical $\left[\left(\mathrm{C}_{23} \mathrm{H}_{32} \mathrm{O}_{2}\right)^{+\cdot} \mathrm{SbCl}_{6}{ }^{-}\right]$. A green colored crystal with dimensions $(0.4 \times 0.1 \times 0.1 \mathrm{~mm})$ was prepared as above. $\mathrm{MW}=674.94$, monoclinic, space group $P 21 / c, a=8.7150(5), b=43.106(2)$, and $c=7.9072(4) \AA, D_{c}=1.573$ $\mathrm{mg} \mathrm{m}^{-3}, V=2850.4(3) \AA^{3}, Z=4$. The total number of reflections measured was 13435 , of which 7706 reflections were symmetrically nonequivalent. Final residuals were $R_{1}=0.0702$ and $w R_{2}=0.1035$ for 7419 reflections with $I>2 \sigma(/ 0)$. 1,2,3,4,5,6,7,8-Octamethylbiphenylene Cation Radical $\left[\left(\mathrm{C}_{20} \mathrm{H}_{24}\right)_{2}{ }^{+\cdot} \mathrm{SbCl}_{6}{ }^{-}\left(\mathrm{C}_{6} \mathrm{H}_{15} \mathrm{O}\right)+{ }^{+} \mathrm{SbCl}_{6}{ }^{-}\right]$. A mixture of octamethylbiphenylene (0.5 $\mathrm{mmol})$ and $\left[\mathrm{Et}_{3} \mathrm{O}^{+} \mathrm{SbCl}_{6}\right](0.75 \mathrm{mmol})$ in anhydrous dichloromethane $(20 \mathrm{~mL})$ was stirred at 0 ${ }^{\circ} \mathrm{C}$ for $1 \mathrm{~h}$. The highly colored solution was filtered under an argon atmosphere and was carefully layered with anhydrous toluene $(30 \mathrm{~mL})$. The bilayered solution was placed in a refrigerator $\left(-23^{\circ} \mathrm{C}\right)$, and during 3 days, a well-formed crop of almost black crystals was obtained. A dark-colored crystal with dimensions $(0.5 \times 0.3 \times 0.25 \mathrm{~mm})$ was selected for data collection. $\mathrm{MW}=869.25$, monoclinic, space group $P 21 / c, a=7.4495(3), b=15.8211(7)$, and $c$ $=29.0815(12) \AA, D_{c}=1.698 \mathrm{mg} \mathrm{m}^{-3}, V=3399.9(2) \AA^{3}, Z=4$. The total number of reflections measured was 32181, of which 11804 reflections were symmetrically nonequivalent. Final residuals were $R_{1}=0.0566$ and $w R_{2}=0.0928$ for 11789 reflections with $I>2 \sigma(I 0)$. [Interestingly, triethyloxonium hexachloroantimonate cocrystallized with the mixed-valence (8) $2^{+\bullet}$ salt. The crystallographic solution revealed that triethyloxonium moiety was completely ordered in this structure, and it allowed the molecular geometry of $\mathrm{Et}_{3} \mathrm{O}^{+}$to be established unambiguously. Moreover, this finding is significant because the previous attempts to obtain an ordered structure of triethyloxonium cations were unsuccessful]. .5 Triethyloxonium Hexachloroantimonate $\left[\left(\mathrm{C}_{6} \mathrm{H}_{15} \mathrm{O}\right)^{+} \mathrm{SbCl}_{6}{ }^{-}\right]$. A colorless crystal with dimensions $(0.4 \times 0.1 \times$ $0.1 \mathrm{~mm}$ ) was obtained from a mixture of dichloromethane and hexane at $0{ }^{\circ} \mathrm{C}$. $\mathrm{MW}=437.63$, tetragonal, space group $P 4 / n c c, a=10.88010(10), b=10.88010(10)$, and $c=15.9951(3) \AA, D_{c}$ $=1.535 \mathrm{mg} \mathrm{m}^{-3}, V=1893.45(4) \AA^{3}, Z=4$. The total number of reflections measured was 1647 , of which 1717 reflections were symmetrically nonequivalent. Final residuals were $R_{1}=0.0489$ and $w R_{2}=0.1353$ for 1745 reflections with $I>2 \sigma(I 0)$. [Note that in this X-ray structure of free $\left[\mathrm{Et}_{3} \mathrm{O}^{+} \mathrm{SbCl}_{6}\right]$ the triethyloxonium cation is heavily disordered. $]^{45}$

\section{Acknowledgment}

We thank the National Science Foundation and Robert A. Welch Foundation for financial support. 
This article references 45 other publications.

(1) (a) Hart, H.; Teuerstein, A.; Babin, M. A. J. Am. Chem. Soc. 1981, 103, 903. (b) Bhattacharya, A.; DiMichele, L. M.; Dolling, U.-H.; Grabowski, E. J. J.; Grenda, V. J. J. Org. Chem. 1989, 54, 6118. (c) Andersen, M. L.; Handoo, K. L.; Parker, V. D. Acta Chem. Scand. 1991, 45, 983. (d) Bauld, N. L.; Bellville, D. J.; Harirchian, B.; Lorenz, K. T.; Pabon, P. A., Jr.; Reynolds, D. W.; Wirth, D. D.; Chiou, H. S.; Marsh, B. K. Acc. Chem. Res. 1987, 20, 371. (e) Kita, Y.; Tohma, H.; Hatanaka, K.; Takada, T.; Fujita, S.; Mitoh, S.; Sakurai, H.; Oka, S. J. Am. Chem. Soc. 1994, 116, 3864.

2 (a) Chanon, M. Bull. Soc. Chim. Fr. 1985, 209. (b) Eberson, L. Electron-Transfer Reactions in Organic Chemistry; Springer: New York, 1987. (c) Dinnocenzo, J. P.; Banach, T. E. J. Am. Chem. Soc. 1986, 108, 6063. (d) Richardson, T. J.; Bartlett, N. J. Chem. Soc., Chem. Commun. 1974, 427. (e) Snider, B. B.; Kwon, T. J. Org. Chem. 1990, 55, 4786. (f) Panday, G. Top. Curr. Chem. 1993, 168, 175.

3.(a) Connelly, N. G.; Geiger, W. E. Chem. Rev. 1996, 96, 877. (b) McClend, C. W. In Synthetic Reagents; Pizey, J. S., Ed.; Wiley: New York, 1983; p 85. (c) Uemura, S. In Synthetic Reagents; Pizey, J. S., Ed.; Wiley: New York, 1983; p 165. (d) Bock, H.; Brähler, G.; Henkel, U.; Schleker, R.; Seebach, D. Chem. Ber. 1980, 113, 289. (e) Mijs, W. J.; deJonge, C. R. H. I. Organic Synthesis by Oxidation by Metal Complexes; Plenum: New York, 1986.

4 (a) Chanon, M.; Fox, M.-A. Photoinduced Electron Transfer, Parts A-D; Elsevier: Amsterdam, 1988. (b) Roth, H. D. Top. Curr. Chem. 1992, 163, 131. (c) Mattay, J. Synthesis 1989, 233. (d) Yoshida, K. Electrooxidation in Organic Chemistry. The Role of Cation Radicals as Synthetic Intermediates; Wiley: New York, 1984. (e) Kyriacou, D. Modern Electroorganic Chemistry; Springer: Berlin, 1994. (f) Also see: Fry, A. J. Synthetic Organic Electrochemistry; Wiley: New York, 1989.

5(a) Brandys, M.; Sassoon, R. E.; Rabani, J. J. Phys. Chem. 1987, 91, 953. (b) O'Neill, P.; Steenken, S.; Schulte-Frohlinde, D. J. Phys. Chem. 1975, 79, 2773. (c) For a review see: Baxendale, J. H.; Rodgers, M. A. J. Chem. Soc. Rev. 1978, 7, 235 and references therein.

6(a) Enkelmann, V. Synth. Met. 1991, 42, 2547. (b) Yoshizawa, K.; Chano, A.; Ito, A.; Tanaka, K.; Yamabe, T.; Yamauchi, J.; Shiro, M. J. Am. Chem. Soc. 1992, 114, 5994. (c) Rathore, R.; Lindeman, S. V.; Kochi, J. K. Angew. Chem. Int. Ed. 1998, 37, 1585.

?(a) Law, K. Y. Chem. Rev. 1993, 93, 449. (b) Baumgarten, M.; Müllen, K. Top. Curr. Chem. 1994, 169, 1.

${ }^{8}$ Determined by searching through the Cambridge Crystallography Data Base (Release Fall 1997).

9With strong electrophilic properties and prone to rapid proton loss, fragmentation, etc. See:

(a) Schmittel, M.; Burghart, A. Angew. Chem., Int. Ed. Engl. 1997, 36, 2550. (b) Albini,

A.; Fasani, E.; Dalessandro, N. Coord. Chem. Rev. 1993, 125, 269.

${ }^{10}$ (a) Musker, W. K.; Woldford, T. L. J. Am. Chem. Soc. 1976, 98, 3055. (b) Also see: Bandlish, B. K.; Shine, H. J. J. Org. Chem. 1977, 42, 561.

11(a) Bell, F. A.; Ledwith, A.; Sherrington, D. C. J. Chem. Soc. C 1969, 13, 2719. (b) Luken, E.

A. C. J. Chem. Soc. 1969, 4963. (c) Cowell, G. W.; Ledwith, A.; White, A. C.; Woods, H.

J. J. Chem. Soc. B 1970, 227.

12For example, the stoichiometry: $\mathrm{ArH}+\mathrm{NO}^{+} \mathrm{X}^{-} \rightarrow \mathrm{ArH}^{+} \mathrm{X}^{-}+\mathrm{NO}$.

$\underline{13}$ Kim, E. K.; Kochi, J. K. J. Am. Chem. Soc. 1991, 113, 4962. 
$\underline{14}$ (a) Meerwein, H.; Battenberg, E., Gold, H.; Pfeil, E.; Willfang, G. J. Prakt. Chem. 1939, 154, 83. (b) Previous indications that triethyloxonium hexachloroantimonate can be involved in other than ethylation reactions were reported by Böttger, G.; Geisler, A.; Fröhlich, R.; Wüthwein, E.-U. J. Org. Chem. 1997, 62, 6407 and references therein.

15(a) Rathore, R.; Kochi, J. K. J. Org. Chem. 1995, 60, 4399. (b) Rathore, R.; Kochi, J. K. Acta Chem. Scand. 1998, 52, 114. (c) Tanaka, F.; Mataga, N. Bull. Chem. Soc. Jpn. 1973, 46, 1591.

$\underline{16}$ (a) The reduced antimony(III) trichloride moiety has been crystallographically identified as a (polymeric) chloride complex. (b) Rathore, R.; Lindeman, S. V.; Kumar, A. S.; Kochi, J. K. J. Am. Chem. Soc. 1998, 120, 6931-6939.

17Smith, J. R. L.; McKeer, L. C.; Tayler, J. M. J. Chem. Soc., Perkin Trans. 2 1988, 385.

18 (a) Kovacic, P.; Sparks, A. K. J. Am. Chem. Soc. 1960, 82, 5740. (b) Kovacic, P. In Friedel Crafts and Related Reactions, Vol. IV; Olah, G. A., Ed.; Interscience: New York, 1965. (c) Rathore, R.; Loyd, S. H.; Kochi, J. K. J. Am. Chem. Soc. 1994, 116, 8414.

19 (a) Nugent, W. A. J. Org. Chem. 1980, 45, 4533. (b) Shouji, E.; Yamamoto, K.; Tsuchida, E. Chem. Lett. 1993, 1927. (c) Mori, T.; Rathore, R.; Lindeman, S. V.; Kochi, J. K. J. Chem. Soc., Chem. Commun. 1998, 927.

${ }^{20} \mathrm{Cyclic}$ voltammetry showed that 1-methoxynaphthalene was irreversibly oxidized $\left(E^{\mathrm{p}} \mathrm{ox}=1.60\right.$ $\checkmark$ vs SCE in dichloromethane containing $n$-tetrabutylammonium hexafluorophosphate) at a scan rate of $200 \mathrm{mV} \mathrm{s}^{-1}$.

$\underline{21}$ Radner, F. Acta Chem. Scand. 1989, 43, 481.

222Rathore, R.; Lindeman, S. V.; Kochi, J. K. J. Am. Chem. Soc. 1997, 119, 9393.

23 Meerwein, H.; Hinz, G., Hoffman, P.; Kroning, E.; Pfeil, E. J. Prakt. Chem. 1937, 147, 257. Also see: Perst, H. In Carbonium Ions; Olah, G. A., Schleyer, P., Eds.; Wiley: New York, 1976; Vol. 3, pp $1961 \mathrm{ff}$.

${ }^{24}$ By cyclic voltammetry in dichloromethane containing tetra- $n$-butylammonium hexafluorophosphate at a scan rate of $200 \mathrm{mV} \mathrm{s}^{-1}$.

$\underline{25}$ As such, ethyl transfer from oxygen to chlorine in eq 6 is the microscopic reverse of that involved in the synthesis of [ $\mathrm{Et}_{3} \mathrm{O}^{+} \mathrm{SbCl}_{6}{ }^{-}$, as described by Meerwein et al. in ref 14 .

26-Compare: Cotton, F. A.; Wilkinson, G. Advanced Inorganic Chemistry, 5th ed.; Wiley: New York, 1988; p 395.

27Bard, A. J.; Ledwith, A.; Shine, H. J. Adv. Phys. Org. Chem. 1976, 13, 155. To accommodate the stoichiometry in eq $1, \mathrm{SbCl}_{5}{ }^{*}$ in eq 8 must be converted to $\mathrm{SbCl}_{3}$ (or its equivalent) either via self-disproportionation $\left(2 \mathrm{SbCl}_{5}{ }^{*} \rightarrow \mathrm{SbCl}_{3}+\mathrm{SbCl}_{5}+2 \mathrm{Cl}^{-}\right)$or via oxidation of another aromatic donor $\left(\mathrm{ArH}+\mathrm{SbCl}_{5}^{-\bullet} \rightarrow \mathrm{ArH}^{+\bullet}+\mathrm{SbCl}_{3}+2 \mathrm{Cl}^{-}\right)$.

${ }_{28}^{28}$ As speculatively discussed by Kovacic and co-workers in ref $18 \mathrm{a}$.

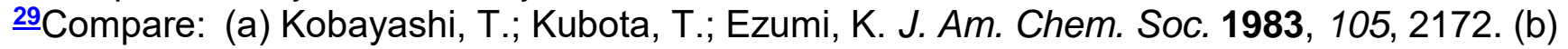
Nakazawa, T.; Murata, I. J. Am. Chem. Soc. 1977, 99, 1996. (c) Inagaki, S.; Yamamura, K.; Nakasugi, K.; Nakazawa, T.; Murata, I. J. Am. Chem. Soc. 1981, 103, 2093.

${ }^{30}$ See: Rathore et al. in ref $15 a$.

311Kunzenhofer, K.; de Boer, J. J. Z. Kristallogr. 1970, 131, 103.

32Badger, B.; Brocklehurst, B. Trans. Faraday Soc. 1969, 65, 2582, 2588.

33Takahashi, S.; Sankararaman, S.; Kochi, J. K. J. Am. Chem. Soc. 1989, 111, 2954.

345ee: Jones, J. B.; Brown, D. S.; Hales, K. A.; Massey, A. G. Acta Crystallogr. 1988, C44, 1757 for the structure of neutral donor. 
${ }^{35}$ Compare the molecular structure of other cationic m-dimers. (a) Kröhnke, C.; Enkelmann, $V$.; Wegner, G. Angew. Chem., Int. Ed. Engl. 1980, 19, 912. (b) Lau, W.; Kochi, J. K. J. Org. Chem. 1986, 51, 1801.

366right, J. D. Molecular Crystals; Cambridge: New York, 1987; p 155 ff.

37Rathore, R.; Bosch, E.; Kochi, J. K. Tetrahedron 1994, 50, 6727.

38 Rathore, R.; Weigand, U.; Kochi, J. K. J. Org. Chem. 1996, 61, 5246.

39 Welch, C. M.; Smith, H. A. J. Am. Chem. Soc. 1951, 73, 4391.

${ }^{40}$ Bosch, E.; Kochi, J. K. J. Am. Chem. Soc. 1996, 118, 1319.

$\underline{41}$ Suter, C. M.; Maxwell, C. E. Org. Synth. Coll. Vol. 2 1943, 485.

42Pentamethylphenylpropanoyl chloride was prepared according to a slightly modified literature procedure (Gasparini, G. M. Gazz. Chim. Ital. 1979, 109, 357). Further details will be published elsewhere.

$\underline{43}$ Jaxa-Chamiec, A.; Shah, V. P.; Kruse, L. I. J. Chem. Soc., Perkin Trans. 1 1989, 1705.

44Sheldrick, G. M. SHELSX-86, Program for Structure Solution; University of Göttingen: Germany, 1986.

45(a) Note that the reported structure of triethyloxonium cation is heavily disordered. See: Watkins, M. I.; Ip, W. M.; Olah, G. A.; Ban, R. J. Am. Chem. Soc. 1982, 104, 2365 and also see Experimental Section. 